\title{
Virus Cancer Research
}

National Cancer Institute

\section{Source}

National Cancer Institute. Virus Cancer Research. NCI Thesaurus. Code C15876.

Experimental or epidemiological studies of viruses as carcinogens or co-carcinogens. 